\title{
Regional Disparities of Stunted Toddler in Indonesia
}

\author{
Agung Dwi Laksono ${ }^{1}$, Ina Kusrini ${ }^{2}$, \\ ${ }^{1}$ Center of Research and Development of Humanities and Health Management, Indonesia \\ Ministry of Health, Jakarta, Indonesia \\ ${ }^{2}$ Unit of Health Research and Development Magelang, Ministry of Health, Center Java, \\ Indonesia \\ *Corresponding Author: \\ Agung Dwi Laksono; agung.dwi.laksono-2016@fkm.unair.ac.id
}

\begin{abstract}
Background/Objective: Although there has been a decline in the prevalence of stunting in Indonesia in the past decade, the figure is still the highest among countries in Southeast Asia. This figure varies in 34 provinces. The purpose of the study was to analyze the regional disparity of stunted toddlers in Indonesia.

Materials and Methods: The analysis in this study uses data from the 2017 Indonesian Nutritional Status Monitoring (PSG 2017). Multi-stage cluster random sampling was used in the PSG 2017. The sample used in this study was 149,571 toddlers aged 0-59 months. Data were analyzed using the Binary Logistic Regression test.

Results: Toddlers in the Sumatra region have the possibility of 0.921 times stunted compared to toddlers in the Papua region (OR 0.921; 95\% CI 0.880-0.963). The Java-Bali region was 0.805 times more likely than toddlers in the Papua region to be stunted (OR 0.805; 95\% CI 0.763-0.843). The Nusa Tenggara Region was 1.394 times more likely than toddlers in the Papua region to be stunted (OR 1.394; 95\% CI 1.315-1.478). Kalimantan Region has 1.161 times more likely than toddlers in the Papua region to be stunted (OR 1.161; 95\% CI 1.1031.223). The Sulawesi region has 1.184 times the possibility of toddlers in the Papua region being stunted (OR 1.184; 95\% CI 1.128-1.243). Maluku region has a probability of 0.884 times that of toddlers in the Papua region to be stunted (OR 0.884; 95\% CI 0.824-0.949).

Conclusion: There was a regional disparity of stunted toddler in Indonesia.
\end{abstract}

Keyword: nutrition status, child nutritional science, nutrition surveys

\section{INTRODUCTION}

A linear growth curve for toddlers with age is the best indicator in describing whether there is quality inequality in achieving optimal children's health [1]. Inadequate food in meeting nutritional needs and the emergence of infectious diseases is the direct and most frequent cause of this growth failure [2]. Stunting is a form of growth failure that reflects 
chronic and multidimensional nutritional problems in the first 1000 days of life that have an impact on the quality of human resources [3-4]. Decreased cognitive abilities, increased morbidity and the onset of metabolic syndrome in the future are the serious effects of stunting [5-6].

Stunting is marked by the $\mathrm{z}$ value of height according to age below -2 standard deviations from the global growth reference. Data from the Global Health Observatory shows that globally nearly 150 million children under five in the world, or around $21.9 \%$, are still in the stunting category. In line with the agenda of public health priorities in the world, it is expected that the prevalence of stunting will decrease by 2030 to 17.5\% [7-8]. Indonesia is a country with a high enough stunting rate. Indonesia Basic Health Survey data for 2007, 2013 and 2018 show the prevalence of national toddler stunting in Indonesia respectively $36.8 \%$; $37.2 \% ; 30.8 \%$ [9]. Although there has been a decrease in the prevalence of stunting in the past decade, the figure still shows more than $30 \%$. This figure is the highest among countries in Southeast Asia. This condition can be interpreted that one in three toddlers born in Indonesia is still stunted. This figure varies in 34 provinces and 541 regencies/cities, which is between $17.6 \%-42.3 \%$ [9].

The success of stunting prevention cannot be separated from cross-sectoral and multidimensional collaboration. One index to measure the success of health development in the national context (Indonesia) is the Public Health Development Index (PHDI). Collection of public health indicators that comprehensively form 1 value that has a connection with life expectancy and is one of the efforts to see the ranking and progress of health development at the regional level [10]. The PHDI data for 2013 and 2018 illustrate the disparity in health development at the regency/city and provincial levels in Indonesia. Differences in the geographical environment, access, socioeconomics as well as human development underlie this inequality. Based on the background, this study was conducted to analyze the regional disparity of stunted toddler in Indonesia.

\section{MATERIALS AND METHODS}

\section{Data Source}

This study analyzes the 2017 Indonesian Nutritional Status Monitoring data (PSG 2017). PSG 2017 was a national-scale survey using a multi-stage cluster random sampling method conducted by the Nutrition Directorate of the Indonesian Ministry of Health [11]. The unit of analysis in this study was toddlers aged 0-59 months. The sample size analyzed in this paper was 149,571 toddlers.

\section{Procedure}

The PSG 2017 already has an ethical license approved by the National Ethics Committee (ethical number: LB.02.01 / 2 / KE.244 / 2017). In this survey, informed consent was used during data collection, which considers aspects of procedures for data collection, voluntary and confidentiality.

\section{Data Analysis}


The region was the division of territory grouped by largest island. Divided into 7 regions, namely Sumatra, Java-Bali, Nusa Tenggara, Kalimantan, Sulawesi, Maluku, and Papua [12]. Stunting was an indicator of nutritional status that was assessed based on height per age, or height of the child achieved at a certain age. The height indicator according to age was determined based on the z-score, or deviation of height compared to normal height according to WHO growth standards. The limit for the category of nutritional status of children under five according to height per age according to WHO is [11]:

- Stunted $\quad:<-2,0 \mathrm{SD}$

- Normal $\quad: \geq-2$ SD

Before conducting a multinomial logistic regression test, a colinearity test was carried out. Then the variable selection was done by using the Chi-Square test to test the dichotomous variable, while for the continuous variable the T-test was used. This statistical test was used to assess whether there was a statistically significant relationship between regional variables and other variables related to the nutritional status of toddlers for height per age. There were 8 variables in 3 groups of variables to be tested, namely the characteristics of children under five (nutritional status and age), the context of the region (urban-rural), and the characteristics of mothers of children under five (age, marital status, education level, work status). A binary logistic regression test was used at the final stage to determine the variables that were predictors of stunting in toddlers in Indonesia.

\section{RESULTS}

Table 1 is the result of the co-linearity test which shows that there is no collinearity between dependent and independent variables. Table 1 shows that the tolerance value of all variables was greater than 0.10 , while the variance inflation factor value for all variables was less than 10.00. Therefore, it was concluded that there were no symptoms of multicollinearity in the regression model.

Table 1. Results for co-linearity test $(\mathrm{n}=149,571)$

\begin{tabular}{lll}
\multicolumn{1}{c}{ Variables } & \multicolumn{2}{c}{ Collinearity Statistics } \\
\cline { 2 - 3 } & Tolerance & VIF \\
\hline Area Context & & \\
$\quad$ Region & 0.984 & 1.016 \\
Area & 0.954 & 1.048 \\
\hline Toddler's Characteristic & & \\
$\quad$ Toddler's Age (in months) & 0.983 & 1.018 \\
Mother's Characteristics & & \\
Mother's Age (in years) & 0.967 & 1.034 \\
Mother's Marital status & 0.995 & 1.005 \\
Mother's Education level & 0.927 & 1.078 \\
Mother's Work Status & 0.959 & 1.043 \\
\hline
\end{tabular}


Table 2 is a statistical description of the region and variables related to the nutritional status of children under five as the focus of this study. Table 2 shows that on average each region is dominated by rural areas. On average, each region is dominated by toddlers with normal nutritional status. The largest prevalence of stunted children is in the Nusa Tenggara region. There is a significant difference between the nutritional status of children under five by region category in Indonesia. Table 2 shows that the average age of children under five is slightly older in the Papua region compared to mothers of children under five in other regions. While the average age of mothers of children under five is slightly older in the Nusa Tenggara region compared to mothers of children under five in other regions

Table 2 shows that based on marital status, toddlers in all dominant regions have married status. While based on the level of education of mothers of children under five in the region of Sumatra, Java-Bali, Sulawesi, and Maluku, they have a dominant high school education. While the regions of Nusa Tenggara, Kalimantan and Papua predominantly have primary school and under. Table 2 shows that based on work status, mothers of toddler are dominated by those who do not work.

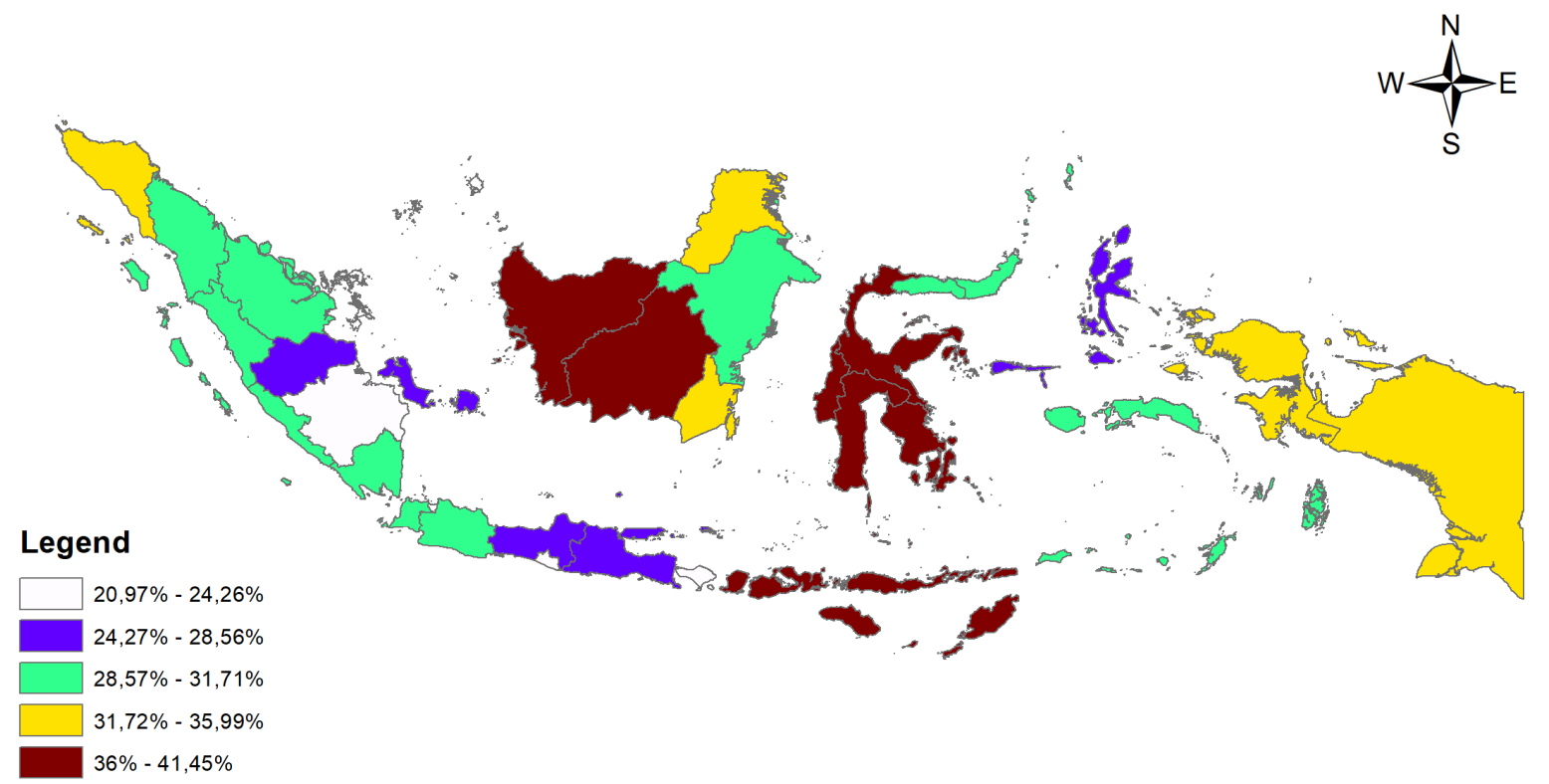

Figure 1. Distribution of Stunted Toddler by Province in Indonesia $(n=149,571)$

Figure 1 shows an overview of the distribution of stunted toddlers by the province in Indonesia. The highest prevalence is seen in the Nusa Tenggara, Kalimantan and Sulawesi regions. While the Java-Bali and Maluku regions are in the middle and low categories. 
Tabel 2. Socio-Demographic of Region and Variables Related to Nutrition Status of Toddlers $(n=149,571)$

\begin{tabular}{|c|c|c|c|c|c|c|c|c|c|}
\hline \multirow[b]{2}{*}{ Variables } & \multicolumn{7}{|c|}{ Region } & \multirow[b]{2}{*}{ All } & \multirow[b]{2}{*}{$\mathrm{P}$} \\
\hline & Sumatra & Java-Bali & $\begin{array}{c}\text { Nusa } \\
\text { Tenggara }\end{array}$ & Kalimantan & Sulawesi & Maluku & Papua & & \\
\hline \multicolumn{10}{|l|}{ Area Context } \\
\hline Area & & & & & & & & & $<0.001$ \\
\hline - Urban & $\begin{array}{l}11396 \\
(25.1 \%)\end{array}$ & $\begin{array}{c}12477 \\
(33.8 \%)\end{array}$ & $2133(22.8 \%)$ & $4089(25.0 \%)$ & $6200(26.0 \%)$ & $1017(17.4 \%)$ & $2348(19.8 \%)$ & $39660(26.5 \%)$ & \\
\hline - Rural (Ref.) & $\begin{array}{c}33933 \\
(74.9 \%) \\
\end{array}$ & $\begin{array}{l}24476 \\
(66.2 \%) \\
\end{array}$ & $7217(77.2 \%)$ & $\begin{array}{c}12270 \\
(75.0 \%)\end{array}$ & $\begin{array}{c}17652 \\
(74.0 \%)\end{array}$ & $4824(82.6 \%)$ & $9539(80.2 \%)$ & $109911(73.5 \%)$ & \\
\hline \multicolumn{10}{|l|}{ Toddler's Characteristic } \\
\hline Nutrition Status & & & & & & & & & $<0.001$ \\
\hline - Stunted & $\begin{array}{c}13652 \\
(30.1 \%)\end{array}$ & $\begin{array}{c}10056 \\
(27.2 \%)\end{array}$ & $3738(40.0 \%)$ & $5897(36.0 \%)$ & $8539(35.8 \%)$ & $1654(28.3 \%)$ & $4047(34.0 \%)$ & $47583(31.8 \%)$ & \\
\hline - Normal (Ref.) & $\begin{array}{c}31677 \\
(69.9 \%) \\
\end{array}$ & $\begin{array}{c}26897 \\
(72.8 \%) \\
\end{array}$ & $5612(60.0 \%)$ & $\begin{array}{c}10462 \\
(64.0 \%)\end{array}$ & $\begin{array}{c}15313 \\
(64.2 \%) \\
\end{array}$ & $4187(71.7 \%)$ & $7840(66.0 \%)$ & $101988(68.2 \%)$ & \\
\hline $\begin{array}{l}\text { Toddler's Age (in months; } \\
\text { mean) }\end{array}$ & $45329(26.4)$ & $36953(26.1)$ & $9350(26.5)$ & $16359(26.6)$ & $23852(26.5)$ & $5841(24.6)$ & $11887(27.0)$ & $149571(26.4)$ & $<0.001$ \\
\hline \multicolumn{10}{|l|}{ Mother's Characteristics } \\
\hline $\begin{array}{l}\text { Mother's Age (in years; } \\
\text { mean) }\end{array}$ & $45329(30.2)$ & $36953(30.7)$ & $9350(31.1)$ & $16359(29.7)$ & $23852(30.0)$ & $5841(30.7)$ & $11887(28.6)$ & $149571(30.2)$ & $<0.001$ \\
\hline Mother's Marital status & & & & & & & & & $<0.001$ \\
\hline - Never Married & $163(0.4 \%)$ & $79(0.2 \%)$ & $157(1.7 \%)$ & $72(0.4 \%)$ & $105(0.4 \%)$ & $32(0.5 \%)$ & $124(1.0 \%)$ & $732(0.5 \%)$ & \\
\hline - Married & $44739(98.7 \%)$ & $36463(98.7 \%)$ & $9014(96.4 \%)$ & $16077(98.3 \%)$ & $23433(98.2 \%)$ & $5756(98.5 \%)$ & $11540(97.1 \%)$ & $147022(98.3 \%)$ & \\
\hline - Divorced/Widowed (Ref.) & $427(0.9 \%)$ & $411(1.1 \%)$ & $179(1.9 \%)$ & $210(1.3 \%)$ & $314(1.3 \%)$ & $53(0.9 \%)$ & $223(1.9 \%)$ & $1817(1.2 \%)$ & \\
\hline Mother's Education level & & & & & & & & & $<0.001$ \\
\hline - Primary school and Under & $\begin{array}{c}11158 \\
(24.6 \%)\end{array}$ & $9556(25.9 \%)$ & $3682(39.4 \%)$ & $5771(35.3 \%)$ & $7069(29.6 \%)$ & $1476(25.3 \%)$ & $5878(49.4 \%)$ & $44590(29.8 \%)$ & \\
\hline - Junior high school & $\begin{array}{l}11276 \\
(24.9 \%)\end{array}$ & $\begin{array}{c}10486 \\
(28.4 \%)\end{array}$ & $2050(21.9 \%)$ & $4253(26.0 \%)$ & $6188(25.9 \%)$ & $1216(20.8 \%)$ & $2053(17.3 \%)$ & $37522(25.1 \%)$ & \\
\hline - Senior high school & $\begin{array}{c}17961 \\
(39.6 \%)\end{array}$ & $\begin{array}{l}13816 \\
(37.4 \%)\end{array}$ & $2631(28.1 \%)$ & $4903(30.0 \%)$ & $7942(33.3 \%)$ & $2296(39.3 \%)$ & $3038(25.6 \%)$ & $52587(35.2 \%)$ & \\
\hline - College (Ref.) & $4934(10.9 \%)$ & $3095(8.4 \%)$ & $987(10.6 \%)$ & $1432(8.8 \%)$ & $2653(11.1 \%)$ & $853(14.6 \%)$ & $918(7.7 \%)$ & $14872(9.9 \%)$ & \\
\hline Mother's Work Status & & & & & & & & & $<0.001$ \\
\hline - No Work & $\begin{array}{c}33117 \\
(73.1 \%)\end{array}$ & $\begin{array}{l}25576 \\
(69.2 \%)\end{array}$ & $5009(53.6 \%)$ & $\begin{array}{c}12719 \\
(77.7 \%)\end{array}$ & $\begin{array}{c}18615 \\
(78.0 \%)\end{array}$ & $4074(69.7 \%)$ & $6390(53.8 \%)$ & $105500(70.5 \%)$ & \\
\hline - Work (Ref.) & $\begin{array}{l}12212 \\
(26.9 \%) \\
\end{array}$ & $\begin{array}{l}11377 \\
(30.8 \%) \\
\end{array}$ & $4341(46.4 \%)$ & $3640(22.3 \%)$ & $5237(22.0 \%)$ & $1767(30.3 \%)$ & $5497(46.2 \%)$ & $44071(29.5 \%)$ & \\
\hline
\end{tabular}

Note: ${ }^{*} \mathrm{p}<0.05 ;{ }^{* *} \mathrm{p}<0.01 ;{ }^{* * *} \mathrm{p}<0.001$. 


\section{Multivariate Analysis}

Table 3 displays the results of the binary logistic regression of the nutritional status of the toddler. Table 3 shows that in the Sumatra, Java-Bali, Nusa Tenggara, Kalimantan, Sulawesi, and Maluku regions, the stunted incidence disparity in toddlers has proven to be significant compared to the Papua region as a reference.

Table 3 informs that toddlers in the Sumatra region are 0.921 times more likely than toddlers in the Papua region to be stunted (OR 0.921; 95\% CI 0.880-0.963). The Java-Bali region is 0.805 times more likely than toddlers in the Papua region to be stunted (OR 0.805; 95\% CI 0.763-0.843). The Nusa Tenggara Region is 1,394 times more likely than toddlers in the Papua region to be stunted (OR 1.394; 95\% CI 1.315-1.478). Kalimantan Region has 1.161 times more likely than toddlers in the Papua region to be stunted (OR $1.161 ; 95 \%$ CI 1.103-1.223). The Sulawesi region has 1.184 times the possibility of toddlers in the Papua region being stunted (OR 1.184; 95\% CI 1.128-1.243). Maluku region has a probability of 0.884 times that of toddlers in the Papua region to be stunted (OR 0.884; 95\% CI 0.8240.949). It could be interpreted that toddler in the Sumatra, Java-Bali, and Maluku regions had a lower possibility than the Papua region to be stunted. While the Nusa Tenggara, Kalimantan, and Sulawesi regions had a greater possibility than the Papua region to experience stunted.

Table 3. Multinomial Logistic Regression of Nutritional Status of Toddler ( $n=149,571)$

\begin{tabular}{|c|c|c|c|}
\hline \multirow[b]{2}{*}{ Predictors } & \multicolumn{3}{|c|}{ Stunted } \\
\hline & OR & $\begin{array}{l}\text { Lower } \\
\text { Bound }\end{array}$ & $\begin{array}{l}\text { Upper } \\
\text { Bound }\end{array}$ \\
\hline \multicolumn{4}{|l|}{ Region } \\
\hline Region: Sumatra & $* * * 0.921$ & 0.880 & 0.963 \\
\hline Region: Java-Bali & $* * * 0.805$ & 0.768 & 0.843 \\
\hline Region: Nusa Tenggara & $* * * 1.394$ & 1.315 & 1.478 \\
\hline Region: Kalimantan & $* * * 1.161$ & 1.103 & 1.223 \\
\hline Region: Sulawesi & $* * * 1.184$ & 1.128 & 1.243 \\
\hline Region: Maluku & $* * 0.884$ & 0.824 & 0.949 \\
\hline \multicolumn{4}{|l|}{ Area Context } \\
\hline Area: Urban & $* * * 0.814$ & 0.792 & 0.836 \\
\hline \multicolumn{4}{|l|}{ Toddler's Characteristic } \\
\hline Age & $* * * 1.028$ & 1.027 & 1.029 \\
\hline \multicolumn{4}{|l|}{ Mother's Characteristics } \\
\hline Age & $* * * 0.996$ & 0.995 & 0.998 \\
\hline Marital Status: never married & 1.018 & 0.848 & 1.222 \\
\hline Marital Status: married & $* * 0.848$ & 0.769 & 0.936 \\
\hline Education: under primary school & $* * * 1.841$ & 1.759 & 1.926 \\
\hline Education: junior high school & $* * * 1.597$ & 1.524 & 1.673 \\
\hline Education: senior high school & $* * * 1.333$ & 1.275 & 1.394 \\
\hline Work Status: No Work & $* 1.030$ & 1.003 & 1.057 \\
\hline
\end{tabular}


Table 3 informs that toddlers living in urban areas are 0.814 times more likely to be stunted than toddlers living in rural areas. (OR 0.814; 95\% CI 0.792-0.836). This means that toddlers living in urban areas were less likely to be stunted. Table 3 also shows that age, both in infants and mothers, proved to be a significant predictor of stunted events in infants.

Table 3 shows that the mother's characteristics found to be predictors, besides age, are marital status, education, and work status. A toddler who has a married mother is 0.848 times stunted than a toddler who has a divorced/widowed mother (OR 0.848; 95\% CI 0.7690.936). This means toddlers who have married mothers have a lower risk of being stunted.

Table 3 shows that the lower the mother's education level, the toddler is more likely to be stunted than a toddler who has a college graduate mother. A toddler who has a nonworking mother is 1.030 times stunted than a toddler who has a working mother (OR 1.030; 95\% CI 1.275-1.394). This means that toddlers who have mothers who do not work are less likely to experience stunted.

\section{DISCUSSION}

The analysis found that toddlers in Sumatra, Java-Bali, and Maluku regions had a lower risk than the Papua region to be stunted, while the Nusa Tenggara, Kalimantan, and Sulawesi regions had a greater risk than the Papua region to be stunted. These results are in line with some of the results of other studies that found that health development in the West (Sumatra, Java-Bali) has a better tendency than in Eastern Indonesia [12].

The analysis shows that urban areas have a lower risk of stunted children. This result is in line with the results of research in several countries which found that people who live in urban areas tend to have better health status. The tendency for better health status in this urban area is found in South Africa [13], India [14], Bangladesh [15-16], and Iran [17].

In the context of Indonesia, empirically it is known that the Western region has more urban areas than the Eastern region. The condition of urban areas that are more advanced makes those who live in the area have the opportunity and access to better health services than those in the Eastern region [18-19]. This phenomenon is exacerbated by conditions in Eastern Indonesia which also tend to have an archipelago topographic, which makes physical access difficult [20].

The results of the analysis found that some maternal characteristics also contributed to being stunted in infants. Toddlers who have married mothers have a lower risk of being stunted. Married mothers tend to have better mental states [21-22] because the mother can share the burden and role with her husband. A better parental process will reduce the risk of fives being stunted [23-25].

The analysis shows that the lower the mother's education level, the toddler has a greater risk of being stunted. These results are in line with the results of research in Malawi which found that maternal knowledge also became a predictor of undernutrition in infants. Better mother's knowledge will reduce the risk of undernutrition in infants (26). In line with the results of research in Malawi, findings in India, Bangladesh, and Ethiopia also received the same thing. Women's education can reduce child stunting [27-29]. 
Toddlers who have mothers who do not work are less likely to experience stunted. Working mothers tend to have less time for their children. Poor parental time is also known to have a negative impact on the nutritional status of children [30-31].

\section{CONCLUSIONS}

Based on the results of the present study, it can be concluded that there was a regional disparity of stunted toddlers in Indonesia. While other variables that were found to influence the stunted toddler were rurality, age of toddler, age of mother, marital status of mother, education level of mother, and work status of mother. The results of this study are important for policymakers to determine the region target of an accelerated intervention program to reduce the prevalence of stunting in children under five appropriately in Indonesia.

\section{DATA AVAILABILITY}

The 2017 Nutrition Status Monitoring Survey data used to support these findings of this study were supplied by the Directorate of Community Nutrition of the Indonesian Ministry of Health under license and so can not be made freely available. Requests for access to these data should be made to the Directorate of Community Nutrition of the Indonesian Ministry of Health (www.kemkes.go.id).

\section{CONFLICT OF INTEREST}

The authors declare no conflict of interest, financial or otherwise.

\section{ACKNOWLEDGMENTS}

The author would like to thank the Directorate of Community Nutrition of the Ministry of Health of the Republic of Indonesia for allowing to processing of data of the 2017 Nutritional Status Monitoring.

\section{ORCID}

Agung Dwi Laksono https://orcid.org/0000-0002-9056-0399

Ina Kusrini https://orcid.org/0000-0001-6997-4821

\section{REFERENCES}

1. de Onis M, Branca F. Childhood stunting: A global perspective. Matern Child Nutr. 2016;12:12-26.

2. Millward DJ. Nutrition, infection and stunting : the roles of de fi ciencies of individual nutrients and foods, and of in $\mathrm{fl}$ ammation, as determinants of reduced linear growth of children Nutrition Research Reviews. 2017;

3. Fink G, Rockers PC. Childhood growth, schooling, and cognitive development: Further evidence from the Young Lives study. Am J Clin Nutr. 2014;100(1):182-8.

4. Engidaye G, Melku M, Yalew A, Getaneh Z, Asrie F, Enawgaw B. Under nutrition, maternal anemia and household food insecurity are risk factors of anemia among preschool aged children in Menz Gera Midir district, Eastern Amhara, Ethiopia: A 
community based cross-sectional study. BMC Public Health. 2019;19(1):Article number 968.

5. Crookston BT, Dearden KA, Alder SC, Porucznik CA, Stanford JB, Merrill RM, et al. Impact of early and concurrent stunting on cognition. Matern Child Nutr. 2011;7(4):397-409.

6. Li C, Zeng L, Wang D, Allen S, Jaffar S, Zhou J, et al. Growth in early life and physical and intellectual development at school age: A cohort study. $\mathrm{Br} \mathrm{J}$ Nutr. 2019;121(8):866-76.

7. WHO. World Health Assembly Global Nutrition Targets 2025. Stunting Policy Brief. 2015;

8. De Onis M, Blössner M, Borghi E. Prevalence and trends of stunting among preschool children, 1990-2020. Public Health Nutr. 2012;15(1):142-8.

9. National Institute of Health Research and Development of The Indonesia Ministry of Health. The 2018 Indonesia Basic Health Survey (Riskesdas): National Report [Internet]. Jakarta; 2019. Available from: http://labmandat.litbang.depkes.go.id/images/download/laporan/RKD/2018/Laporan _Nasional_RKD2018_FINAL.pdf

10. Suparmi, Kusumawardani N, Nambiar D, Trihono, Hosseinpoor AR. Subnational regional inequality in the public health development index in Indonesia. Glob Health Action. 2018;11(1).

11. Directorate of Community Nutrition of The Ministry of Health of The Republic of Indonesia. the 2017 Indonesia Nutritional Status Monitoring (Pemantauan Status Gizi 2017) [Internet]. Jakarta; 2017. Available from: http://www.kesmas.kemkes.go.id/assets/upload/dir_519d41d8cd98f00/files/BukuSaku-Nasional-PSG-2017_975.pdf

12. Laksono AD, Wulandari RD, Soedirham O. Regional Disparities of Health Center Utilization in Rural Indonesia. Malaysian J Public Heal Med. 2019;19(1).

13. Nyati LH, Pettifor JM, Norris SA. The prevalence of malnutrition and growth percentiles for urban South African children. BMC Public Health. 2019;19(1).

14. Chakrabarti S, Tatavarthy AD. The geography of medical travel in India: Differences across states, and the urban-rural divide. Appl Geogr. 2019;107:12-25.

15. Akram R, Sultana M, Ali N, Sheikh N, Sarker AR. Prevalence and Determinants of Stunting Among Preschool Children and Its Urban-Rural Disparities in Bangladesh. Food Nutr Bull. 2018;39(4):521-35.

16. Islam M, Sultana N. Risk factors for pregnancy related complications among urban slum and non-slum women in Bangladesh. BMC Pregnancy Childbirth. 2019;19(1):Article number 235.

17. Reshadat S, Zangeneh A, Saeidi S, Teimouri R, Yigitcanlar T. Measures of spatial accessibility to health centers: investigating urban and rural disparities in Kermanshah, Iran. J Public Heal. 2019;27(4):519-29.

18. Laksono AD, Wulandari RD, Soedirham O. Urban and Rural Disparities in Hospital Utilization among Indonesian Adults. Iran J Public Health [Internet]. 2019;48(2):24755. Available from: http://ijph.tums.ac.ir/index.php/ijph/article/view/16143

19. Wulandari RD, Laksono AD. Urban-Rural Disparities in The Utilization of Primary Health Care Center Among Elderly in East Java, Indonesia. J Adm Kesehat Indones 
[Internet]. 2019;7(2):in press. Available from: https://ejournal.unair.ac.id/JAKI/article/view/11267

20. Suharmiati, Laksono AD, Astuti WD. Policy Review on Health Services in Primary Health Center in the Border and Remote Area (Review Kebijakan tentang Pelayanan Kesehatan Puskesmas di Daerah Terpencil Perbatasan). Bull Heal Syst Res. 2013;16(2):109-16.

21. Wemakor A, Mensah KA. Association between maternal depression and child stunting in Northern Ghana: A cross-sectional study. BMC Public Health. 2016;16(1):Article number 0163558z.

22. Baptista J, Silva JR, Marques S, Martins C, Soares I. Early Maltreatment and Current Quality of Relational Care Predict Socioemotional Problems Among Institutionalized Infants and Toddlers. Infant Ment Health J. 2018;39(6):718-29.

23. Mulugeta M, Mirotaw H, Tesfaye B. Dataset on child nutritional status and its socioeconomic determinants in Nonno District, Ethiopia. Data Br. 2017;14:6-14.

24. Igbokwe O, Adimorah G, Ikefuna A, Ibeziako N, Ubesie A, Ekeh C, et al. Sociodemographic determinants of malnutrition among primary school aged children in Enugu, Nigeria. Pan Afr Med J. 2017;28:Article number 248.

25. Svefors P, Sysoev O, Ekstrom E-C, Persson LA, Arifeen SE, Naved RT, et al. Relative importance of prenatal and postnatal determinants of stunting: Data mining approaches to the MINIMat cohort, Bangladesh. BMJ Open. 2019;9(8):Article number e025154.

26. Walters CN, Rakotomanana H, Komakech JJ, Stoecker BJ. Maternal determinants of optimal breastfeeding and complementary feeding and their association with child undernutrition in Malawi (2015-2016). BMC Public Health. 2019;19(1):Article number 1503.

27. Pillai VK, Maleku A. Women's education and child stunting reduction in India. J Sociol Soc Welf. 2019;4(3):111-30.

28. Tekile AK, Woya AA, Basha GW. Prevalence of malnutrition and associated factors among under-five children in Ethiopia: Evidence from the 2016 Ethiopia Demographic and Health Survey. BMC Res Notes. 2019;12(1):Article number 391.

29. Talukder A, Razu SR, Hossain MZ. Factors affecting stunting among children under five years of age in Bangladesh. Fam Med Prim Care Rev. 2018;20(4):356-62.

30. Chaturvedi S, Ramji S, Arora NK, Rewal S, Dasgupta R, Deshmukh V, et al. Timeconstrained mother and expanding market: Emerging model of under-nutrition in India. BMC Public Health. 2016;16(1):Article number 632.

31. Laksono AD, Ibad M, Mursita A, Kusrini I, Wulandari RD. Characteristics of mother as predictors of stunting in toddler. Pakistan J Nutr. 2019;18(12):1101-6. 